\title{
The Historical Background of the King James Bible
}

\section{Seda Gasparyan}

Yerevan State University

\begin{abstract}
The present article aims to investigate the historical and religious circumstances which incited King James to initiate and start the translation of the Holy Script anew though two other versions of the Bible in English were already there. The stormy period England and the English Church were going through in mid-XVI century and the succession of Prince James VI of Scotland to throne (who became King James I of England) and his unfavorable attitude towards Protestantism made him conceive the idea of the necessity of creating a new English version of the Bible which will provide appropriate influence on the Church and keep it away from Calvinist views and ideas. Through the employment of the descriptive method, the author on the other hand tries to analyse the most prominent events and activities which preconditioned the creation of the new English version of the Bible, known as the King James Bible, which has long proved to be the best translation of the Bible in English.
\end{abstract}

Key words: Bible translations, the King James Bible, the domineering popularity of the Geneva Bible, to delimit the Puritan effect, modifications of the Bible text.

\section{Introduction}

The investigations of the biblical texts have always been the topic of heated discussions among theologians, linguists as well as representatives of other scientific disciplines. Over the years the biblical stories and testimonies have been persistently challenged by various scholars, with particular emphasis on the language of the Bible. The original texts and manuscripts in Greek, Hebrew and Aramaic were produced over a period in which the living conditions of the 
writers - political, cultural, economic and ecological - varied enormously (Riches 2000). Nevertheless, the Bible is considered, by and large, as the bestselling book of all time with estimation of 100 million copies sold per year and has a tremendous influence upon the history and literature of all Christian cultures. It has been translated approximately 469 languages, and this number continues to increase.

The greatest number of translations of the Holy Bible, which differ from one another in terms of theology and language, has been accomplished in English. This is by no means accidental as at present English is the most widely used language in the world. There are over 200 versions of the Holy Book translated into English - each of them rendering the text slightly differently and claiming to be the best and most precise translation available on the market. However, this was not the case three hundred years ago, when the only English Bible accessible to public at large was the King James Version (KIV), otherwise known as the Authorized Version.

\section{Reasons for Creating a New Translation of the Bible}

The particular translation of the Holy Scripture was accomplished under the reign of King James I in 1611. The Authorized or the King James Version quickly became the standard for English-speaking Protestants. Its elevated language and rhythmical prose has had a profound influence upon the English literature of the past 400 years. Nevertheless, in the beginning of the $20^{\text {th }}$ century new translations of the Bible into the English language were undertaken. The number one motivation for the commencement of renovation of the Biblical texts was induced by the precarious assumption that the language of the King James Bible had become obsolete and out-of-date, which created certain abstracts in the process of reading and comprehending the Word of God. The modifications brought about by the newly translated versions, be that as it may, were not merely confined within the frames of simplifying and modernizing the language, but penetrated into all levels of language structure. As a result, the changes introduced into the linguistic form of an expression have given rise to various changes into their semantic structure as well. Even 
the most trivial substitution of a punctuation mark has brought about some drastic consequences related to the doctrine and theology. The linguistic and, consequently, theological divergences which have been engendered in the result of numerous translations of one and the same text have thereby become an inevitable fact.

In the last century 150 versions of the Bible in English were produced. The question is: why does the English language need over two hundred translation when there are over 400 ethnic languages that can happily live with one or two translations? The answer is evident: the particular tendency of translating, printing and afterwards, selling so many versions is largely conditioned by the amount of money to be gained by publishing yet another 'trendy' translation of God's unchanging Words. However, let us not forget the words of a wise man who once said, "a man with a watch knows what time it is, but the one with

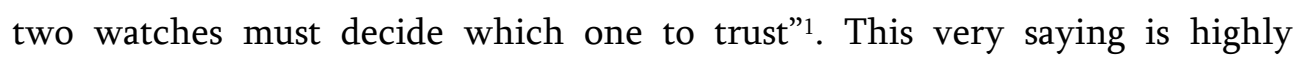
relevant for the depiction of the present abundance of English versions of the Bible.

Nonetheless, despite the presence of so many English versions of the Holy Bible available on the market today, the KJV is still recognized as a standard of comparison by which all other translations are measured. The research carried out within the framework of the present paper aims to study the historical circumstances against the background of which the King James Bible - one of the most outstanding and mysterious phenomena ever, has been created.

The King James Version (KJV) also known as the King James Bible (KJB) is an English translation of the Christian Bible by the Church of England undertaken in 1604 and entirely completed by the end of 1611. It is widely believed that KJV constitutes the only standard by which all other versions and translations are measured. Some people have even gone so far as to claim that $\mathrm{KJV}$ was inspired by God himself and is completely free of errors and imperfections.

King James Bible, however, was only the third translation of the Bible into English that gained the approval of the English Church. The first Bible authorized by the Church of England was the Great Bible that came out in1538 
under the reign of King Henry VIII. The Great Bible was Prepared by Myles Coverdale who extensively made use of Tyndale's Bible (1525). William Tyndale $^{2}$ in his turn had made translations of the Bible into English directly from the Greek and Hebrew texts and manuscripts. However, prior to his execution in 1536 Tyndale had only finished translating the entire New Testament and roughly half of the Old Testament. Thus Coverdale had no other option but to translate the remaining books of the Old Testament and Apocrypha ${ }^{3}$ from the Latin Vulgate and German versions rather than having at one's disposal Aramaic, Hebrew and Greek texts. As a result of working with secondary sources rather than with original texts the Great bible by Coverdale was subsequently regarded inadequate in rendering the "Word of God" and was thereupon superseded by the Bishops' Bible.

\section{The Geneva Bible and the Rejection of the Calvinist Views}

The Bishops' Bible was the second Bible in the English language authorized by the Church of England in 1568. The emergence of the Bishops' Bible was necessitated by the fact that in the second half of the $16^{\text {th }}$ century the spiritual life in England was heavily dominated by the Geneva Bible which propagated the Calvinist ${ }^{4}$ views on the religion and had become the symbol of Protestantism ${ }^{5}$ in England. The Geneva Bible was a specifically significant work as for the first time in history it was mechanically printed and made accessible to public at large. It came out with a variety of marginal notes, footnotes, maps and tables and was often called a study Bible. Nevertheless, this authoritative dominion of the Calvinist Bible (the Geneva Bible) could not leave impartial the high clergymen of the Church of England to which all of the bishops subscribed. They considered Calvinism as a religious movement that aspired to

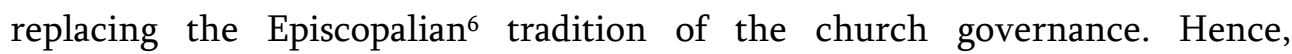
'retaliatory measures' were taken, and the Church of England responded with the Bishops' Bible which was first published in 1568 and republished in an overwhelmingly revised form in 1572. The second version of the Bishops' Bible got rid of those cross-references, footnotes and marginal notes that were present in the Geneva Bible, and which contained much of the controversial theology, 
irrespective of the fact, that they were much of a help to people to whom the Bible was still a new 'device'. In the revised form of the Bishops' Bible (1572) the language was substantially taken to the level of ecclesiastical traditions. The Bishops' Bible obtained the royal authority warrant and became the second Bible (after the Great Bible) which was so highly privileged as to be appointed to be read aloud in church services. However the Bishops' Bible did not come up to expectations as it was printed only in lectern editions and at a cost of several pounds which was not commonly affordable among common people. Consequently, the Geneva Bible persisted in dominating the British market as it came out in small editions and was available at a relatively low cost (Campbell 2010).

Presently, with the death of Queen Elisabeth I7, Prince James VI of Scotland succeeded to the throne, thus becoming King James I of England. The new king was notoriously famous for his hostility to Puritans ${ }^{8}$ and their Calvinist views on religion and church. King James insisted on the divine rights of kings, and his brutality towards the followers of Protestantism had reached the level of utmost severity. Shortly after ascending the throne his primary task became eliminating the popularity commanded by the Geneva Bible and the influence it exerted upon the people of England (Cogswell 1989).

\section{The Approaches and Principles Guiding the Translators}

In July 1604 King James summoned a committee to Hampton Court to get prepared for one of the most influential and significant undertakings that had ever occurred in the history of the English Church. The aim of the congregation was to 'forge' the one and only 'authorized' translation of the Bible that would be accessible to every single citizen inhabiting the British Isles. Thereupon, James I convened all the meetings, planned down the whole process of the translation and financed the entire project. One of the most momentous tasks, i.e. the new translation of the Bible was undertaken by 47 scholars - almost all being members of the Church of England.

The number one task that the translators of KJV were to fulfill was to delimit the Puritan effect on the new version on the one hand, and evade the 
undesirable influence that was indirectly exercised upon the spiritual life of England by the Roman Catholic Church on the other. The most significant peculiarity that made a difference between the KJV and the Geneva Bible was the fact that the translators of KJV were strongly forbidden to add any marginal notes, footnotes or cross-references by which the Geneva Bible had been abundantly characterized. Moreover, King James instructed the scholars to implicate the elevated style of language that would conform to the ecclesiology of the English Church. Particularly, there were a certain number of Greek and Hebrew words that were to be translated in a way as to reflect the traditional use of terminology characteristic of the Church of England. For an example we could refer to the Greek word $\varepsilon \kappa \kappa \lambda \eta \sigma i \alpha^{9}$ which has two meanings: congregation and church. Instead of translating as congregation - as was the case with the Geneva Bible, they rendered it into English as church.

Regardless of the fact that a completely new translation was endeavored, the text of the Bishops' Bible would serve as a starting point, a primary guide for the scholars and translators. This very fact suggested that all the familiar proper names of the biblical characters should be retained. Still, in case the translators faced certain ambiguity in consulting the Bishops' Bible they were permitted to resort to previously published and 'infamously' abandoned bibles, such as the Tyndale's Bible, the Coverdale's Bible, the Great Bible, and even though seemingly incongruous, they could also make use of the Geneva Bible.

Nevertheless, the Authorized Version was translated primarily from the Greek, Hebrew and Aramaic texts, with secondary reference to the Latin Vulgate. The team of the Old Testament translators used a text originating in the editions of the Hebrew Rabbinic Bible ${ }^{10}$. In the $16^{\text {th }}-17^{\text {th }}$ centuries Hebrew scholarship was re-emerging once again from the 'ashes of the unknown'. The scholars working with the Hebrew texts were outstandingly proficient in the Latin, Greek, Hebrew, Aramaic and Arabic languages. In fact the Hebraic proficiency of the Old Testament translators' team included not only knowledge of the Book in the original Hebrew but also accomplishments in the medieval Jewish exegesis and grammar. The Hebrew text which the KJV translators were working on was the one widely known as Leningrad Codex ${ }^{11}$. 
Although the latter could not be classified as very ancient, it could be considered the most complete and reliable manuscript which dates from approximately $1008 \mathrm{AD}$ and constitutes the most important fragment of the Hebrew Bible (McGrath 2002).

Naturally, it was easier to 'dig out' a good deal of proficient specialists of Greek than of Hebrew to translate the New Testament, for virtually all educated Englishmen knew Greek as well as Latin. Ironically, however, the 'squad' of the New Testament translators faced much more disastrous obstacles than they could have envisioned. The number one problem came along the fact that the translators of the New Testament had at their disposal the Greek edition of the New Testament (1588) compiled by no less a man than Theodore Beza - a French Protestant Christian Theologian and scholar who played a significant role in the reformation. More importantly, Beza was a disciple of John Calvin - the most prominent propagator of Puritanism. Consequently, the translators were challenged to solve the problem of eliminating the 'Puritan effect' that was vividly exposed on the surface of Beza's work. Therefore, the $\mathrm{KJV}$ translators were sensitive to the significance of the context in the meaning of words, and they translated the words according to their contextual meaning as well as dictionary definition, thus avoiding the "biased approach and scrupulosity of Puritans" at the same time retaining the capability of shunning the Papists (the Douay-Rheims Bible ${ }^{12}$ ) so that the Scripture may speak by itself and be comprehensible even to the very vulgar.

Eventually, all the translators completed their sections by 1608, Apocrypha committee finishing first. The original printing of the Authorized Version was published by Robert Barker ${ }^{13}$, the King's printer in 1611. The original printing had been made before the English spelling became standardized so printers could usually indulge themselves in expanding and contracting the spelling of one and the same word in different places in order to achieve (for instance) an even column of the text. They would utilize $\boldsymbol{v}$ for initial $\boldsymbol{u}$ and $\boldsymbol{v}$, and $\boldsymbol{u}$ for $\boldsymbol{u}$ and $\boldsymbol{v}$ everywhere else. When there was a necessity to save the space the printers used $y \boldsymbol{e}$ instead of thee, $\ddot{a}$ for an or am, and even $\boldsymbol{\&}$ for and. Conversely, they could also insert the above mentioned words in their complete 
form wherever the lines needed to be padded. Naturally, punctuation was relatively heavy and profoundly different from the modern punctuation rules.

The original printing contained two prefatory texts: "Epistle Dedicatory to the most High and Mighty Prince King James" and "The translators to the readers". The latter represented a critical and explanatory essay where the translators were trying to justify the necessity of creating the new translation of the Bible and its importance to the future generations. They particularly claimed:

"We do not deny, nay we affirm or avow, that the very meanest translation of the Bible in English is set forth by men of our profession (for we have seen none of theirs of the whole Bible as yet) containeth the word of God, nay is the word of God".

However, the wide acceptance of the Authorized Version by public took longer. The Geneva Bible continued to be the most popular version despite the fact that its printing in England had been largely suspended since 1616. The newly published editions of the Geneva Bible were mainly imported to England from Amsterdam. Nonetheless, the overwhelming predominance of the G.B. did not last long as shortly after the English Restoration ${ }^{14}$ it became politically "Biblia non grata" and merely served as a reminder of the temporarily forgotten Puritan era. Thus, since the first half of the $18^{\text {th }}$ century the Authorized Version has become the "ONE and ONLY" version circulating among the English speaking people.

By the mid- $18^{\text {th }}$ century as a result of a 130 -year-old publishing and republishing of the $\mathrm{KJV}$, the Authorized Version accumulated so many notorious misprints and instances of misinterpretations that it could not pass unnoticed. Therefore, a number of scholars from the Universities of Cambridge and Oxford set out to resolve the matter and produce an updated version of the text. The Cambridge edition came first in 1760. It was an outcome of the hard work and dedication by Francis Sawer Parris ${ }^{15}$, who died in the same year of the 
publication of his work. Subsequently, the Cambridge version was heavily superseded by the Oxford edition 1769. The revised version of the Oxford publication was created by Benjamin Blayney ${ }^{16}$, and in comparison to the Cambridge edition it contained comparatively few changes and corrections. Thus, the Cambridge edition became the only valid standard and has been since reprinted almost with no incorporated changes. The changes that were introduced in 1769 publication were of five kinds:

a) Greater use of italics,

b) Minor changes in the text,

c) The adaptation of modern spelling,

d) Changes which consist in incorporating a good deal of marginal notes and references,

e) Corrections of the printers' errors.

Let us move on considering the essential features of these corrections one by one.

a) Use of italics: The KJV was originally printed in the type style known as "black letter". Here, the printed letters were too thick and a huge amount of ink was unscrupulously wasted. It had the following appearance: "The book of the generation of Jesus Christ".

Interestingly enough, the English words in translation that were absent in the original and were merely implicated to make the meaning clearer were more commonly set in small "roman type": "When Herod the king had heard these things, he was troubled".

Yet, in later editions, the ordinary text was set in "roman" type with the supplied words in "italics": When Herod the king had heard these things, he was troubled.

b) Changes in the text. The minor corrections and changes in the text of 1611 edition do not involve corrections of doctrinal or philosophical nature but rather appertain to the changes introduced in spelling rules, capitalization and 
punctuation. Among those changes we may come across, for instance, the following types of alternations:

Mathew 9:34 Omission of the definite article the before

Devil

Mathew 16:16 Omission of the definite article the before

\section{Christ}

Acts 24:24 Jewess instead of Jew

Corinthians 9:5 and instead of not

Eph 4:24 The new man instead of That New Man

c) The adoption of modern spelling: The problems associated with spelling, capitalization and punctuation were of much more problematic character. As we know the period of standardization of the English spelling had started in the late $17^{\text {th }}$ century as a result of the activity of scholars and was completed by the end of the $18^{\text {th }}$ century. The dictionaries and grammars fixed the written forms as obligatory standards; numerous variant spellings of the early Modern English period went out of use. In the $18^{\text {th }}$ century the sound changes slowed down, Standard pronunciation (later known as Received Pronunciation) and standard spelling were firmly established, and the gap between the spoken and written form of the word was perpetuated. The conventional use of letters had prevailed over their original, phonetic use. Thus, we can easily notice that in 1611 edition a great amount of ambiguity in the use of spelling system is detected. For example: feare-fear, shee-she, sonne-son, publique-publick, and\&, sinnes-sins.

d) Capitalization was another problem as the use of capital letters was not fully regular, and in addition to proper nouns that came necessarily in capital form, some common nouns referring, for instance, to important persons were also capitalized. Below we can see the changes that were introduced in 1769 edition, the first chapter of Mathew: Angel of the Lord - angel of the Lord, holy Ghost - Holy Ghost, his Name Jesus - his name Jesus, Behold, a Virgin - Behold, a virgin. 
As far as the punctuation is concerned we shall firmly state that the 1622 edition was more heavily punctuated than the later or more recent editions, for the heavy punctuation was commonly the case for older books.

e) Marginal Notes: Finally, the introduction of marginal notes should be mentioned that indicate various readings and renderings from Greek, Hebrew and Latin manuscripts (Weigle 1962).

As we have already noted, the KJV did not immediately overshadow its predecessors, for the Geneva Bible continued to retain its dominion among average citizens of England. However, by the beginning of the $18^{\text {th }}$ century it had lost its grip on the British public.

Thence, only after 50 years of publication did the victory of KJV become complete. Since then, the KJV has been conceived to be the only valid text that has the sacred right to render the Voice of God. In fact, the KJV prevailed not by demolishing its predecessors, but by learning from them and 'inhaling' all the best that could be detectable in older translations.

\section{Conclusion}

Thus, our study of the historical background of the King James Bible shows that the creation of this version of the Bible was necessitated by the specific tendency of the English Church to shrink away from the dominance of the Roman Papal dictatorship. The accomplishment of this translation was considered to be extremely important for both King James and the English Church as it was the demand of the time, and the committee of the translators carried out their mission brilliantly.

The King James Bible has had an unprecedented influence upon the English language becoming the major source of inspiration for English poets and writers for about three hundred years. Its significance can never be overestimated.

\section{Notes:}

1. A proverb commonly known as Segul's Law. It is a humorous reference to the potential pitfalls of having too much conflicting information before 
making a decision. Retrieved October 5, 2020 from: < https://www. google. com/search?q=Segul\%E2\%80\%99s+Law\&rlz=1C1CHBF_enAM885AM885 \&oq=Segul\%E2\%80\%99s+Law\&aqs=chrome..69i57j0.1674j0j4\&sourceid=ch rome\&ie $=$ UTF-8 $>$

2. William Tyndale an English scholar who became a leading figure in Protestant reform in the years leading up to his execution. He is well known for his translation of the Bible into English. He was influenced by the work of Desiderius Erasmus (a Dutch philosopher and one of the greatest scholars of northern Renaissance) who made the Greek New Testament available in Europe, and by Martin Luther (a German Professor of Theology, priest, author, composer, a seminal figure in the Reformation). Retrieved September 16, 2020 from: <https://www.britannica.com /biography/William-Tyndale>

3. Apocrypha is a name given to the collection of the ancient Biblical books believed to have been written in the period between $200 \mathrm{BC}-400 \mathrm{AD}$ and included in the body of different versions of the Old Testament. Retrieved July 12, 2020 from: <https://en.wikipedia.org/wiki/Biblical_apocrypha\#: : text=The\%20biblical\%20apocrypha\%20(from\%20the,200\%20BC\%20and\% 20400\%20AD.>

4. Calvinism (also called the Reformed tradition or the Reformed faith) is a major branch of Protestantism that follows the theological tradition and forms of Christian practice of John Calvin and other Reformation-era theologians. Calvinists broke with the Roman Catholic Church but differed from Lutherans on the question of the real presence of Christ in the Lord's Supper, theories of worship, and the use of God's law for believers, among other things. Retrieved August 20, 2020 from: <https://en.wikipedia.org/ wiki/Biblical_apocrypha\#: :text=The\%20biblical\%20apocrypha\%20(from \%20the,200\%20BC\%20and\%20400\%20AD>; <https://www.christianity. com/church/denominations/what-is-calvinism.html>

5. Protestantism, being a "branch" of Christianity, however encompasses forms of Christian faith and practice that originated with doctrines and religious, political and ecclesiological impulses of the Protestant 
Reformation against what they considered the errors of the Roman Catholic Church. The term refers to the letter of protestation by Lutheran princes against the decision of the Diet of Speyer in 1529, which reaffirmed the edict of the Diet of Worms condemning the teachings of Martin Luther as heresy. However, the term has been used in several different senses, often as a general term to refer to Western Christianity that is not subject to papal authority, including some traditions that were not part of the original Protestant movement. Retrieved August 8, 2020 from: $<$ https://www.britannica.com/topic/Protestantism/The-Reformation-inEngland-and-Scotland>; https://www.britannica.com/topic/Protestantism>

6. The Episcopal Church stands squarely in the Reformed, or Protestant, tradition and yet they consider themselves to be equally directly descended from the early Church as the Roman Catholic or Eastern Orthodox churches. While we worship in ways similar to the Roman Catholic tradition, we do not recognize a single authority, such as the Pope. The Episcopal Church is often referred to as the "middle way" since it contains elements of both the Catholic Church and Protestant Churches. Retrieved August 10, 2020 from: <https://en.wikipedia.org/wiki/Anglican_Episcopal_ Church>

7. Elizabeth I (7 September 1533 - 24 March 1603) was queen regnant of England and Ireland from 17 November 1558 until her death. Sometimes called "The Virgin Queen", "Gloriana” or "Good Queen Bess”, Elizabeth was the fifth and last monarch of the Tudor dynasty. Retrieved September 15, 2020 from: <https://en.wikipedia.org/wiki/Elizabeth_I>

8. The Puritans were a group of English Protestants in the 16th and 17th centuries, including, but not limited to, English Calvinists. Puritanism in this sense was founded by some Marian exiles from the clergy shortly after the accession of Elizabeth I to the throne of England in 1558, as an activist movement within the Church of England. Retrieved September 5, 2020 from: https://www.history.com/topics/colonial-america/puritanism 


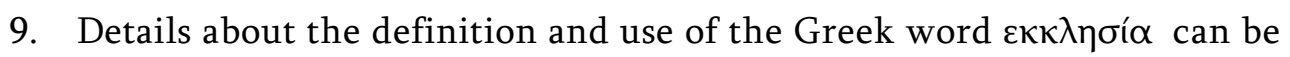
found in D. [Dimitrios] Dimitrakos (1964) Mega Lexikon Olis tis Ellinikis Glossis, vol. 5, Athens n.d.: Hellenic Paideia, p. 2343.

10. Hebrew Rabbinic Bible is a volume covering Jewish texts of great importance which were compiled in Palestine and Babylonia in Late Antiquity. In fact it is an edition of Tanakh (in Hebrew). Retrieved September 8, 2020 from: <https:/www.bl.uk/collection-items/the-greatrabbinic-bible>

11. The Leningrad Codex is the oldest complete Hebrew Bible still in existence today. While there are older codex's of Bibles still in existence (i.e. the Aleppo Codex), they are not the complete text of the Hebrew Bible, containing all the books of the Bible. The Leningrad Codex is considered one of the best examples of the Masoretic text (which serves as basis for the Old Testament translations, the King James version included) represented by the Ben-Asher family. Retrieved July 23, 2020 from: $<$ https://www.jewishvirtuallibrary.org/the-leningrad-codex>

12. The Douay-Rheims Bible is an English version of the Bible translated from Latin Vulgate which in its turn had been translated from Hebrew, Aramaic and Greek texts. Retrieved August 4, 2020 from: $<$ http://www.douayrheimsaudiobible.org/>

13. Robert Barker (died 1645) was a printer to James I of England and son of Christopher Barker, who had been primer to Queen Elizabeth I. Barker was most notably the printer of the King James Bible, one of the most influential and important books ever printed in the English language.

14. The Restoration of the monarchy began in 1660 when the English, Scottish and Irish monarchies were all restored under Charles II after the Interregnum that followed the Wars of the Three Kingdoms. The term Restoration may apply to the actual event by which the monarchy was restored, and to the period immediately following the event. Retrieved August 5, 2020 from: <https://www.history.com/this-day-in-history/theenglish-restoration> 
15. Francis Sawyer Parris $(1707$ - 60) was an English biblical scholar. His textual corrections, italicizations, marginal notes, column headings and cross-references played a major part in updating and standardizing the 1611 Authorized King James Version of the Bible. Retrieved August 10, 2020 from: <https://en.wikipedia.org/wiki/Francis_Parris>

16. Blayney, Benjamin (1727/8 - 1801), Hebraist and a clergyman in the Church of England. Retrieved August 12, 2020 from: <https://www.oxforddnb.com/view/10.1093/ref:odnb/9780198614128.001.0 001/odnb-9780198614128-e-2628>

\section{References:}

1. Campbell, G. (2010) The Story of the King James Version. London: OUP.

2. Cogswell, Th. (1989) The Blessed Revolution: English Politics and the Coming of War, 1621-1624. New York: CUP.

3. McGrath, A. (2002) In the Beginning: The Story of the King James Bible. Newcastle: Anchor.

4. Riches, J. (2000) The Bible: A Very Short Introduction. Oxford: OUP.

5. Weigle, L.A. (1962) New Testament Octapla: Eight English Versions of the New Testament. In the Tyndale - King James Tradition. Available at: <https://www.biola.edu/talbot/ce20/database/luther-allan-weigle> [Accessed May 2020].

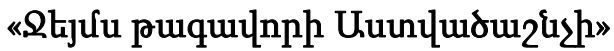

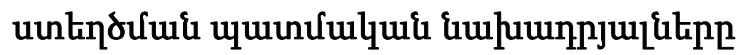

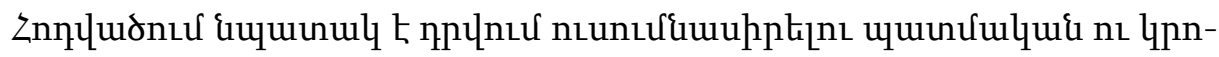

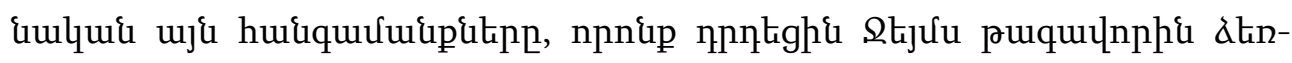

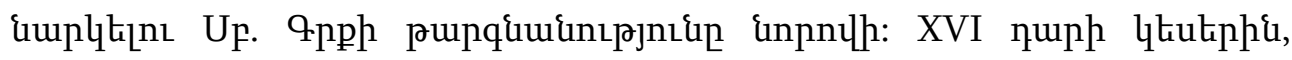

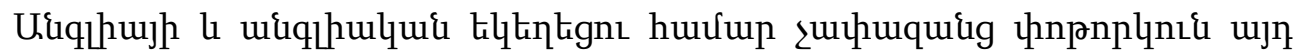

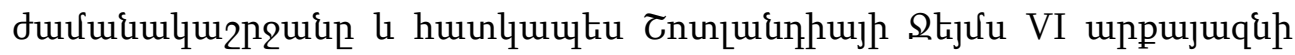

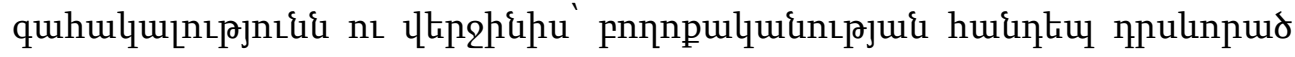

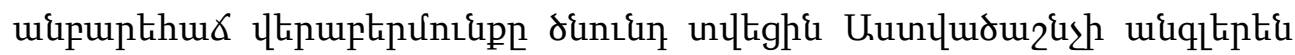




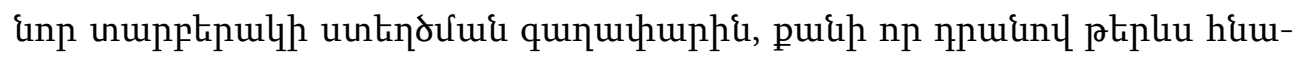

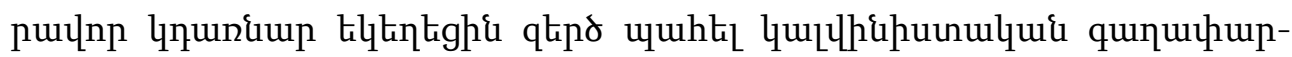
ditphg:

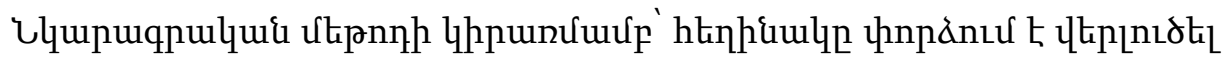

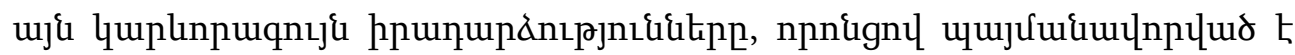

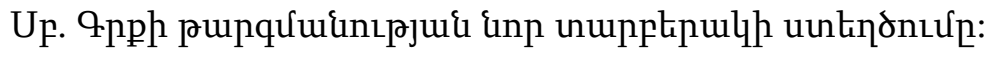

Received by the Editorial Board 19.08.2020

Recommended for publication by the reviewers 07.09 .2020

Accepted for print 05.10 .2020 